\title{
Executive Clemency During the Coronavirus Pandemic: A Global Analysis of Law and Practice
}

\author{
Andrew Novak ${ }^{1}$ (D) Daniel Pascoe ${ }^{2}$
}

Received: 25 August 2021 / Accepted: 7 February 2022 / Published online: 17 February 2022

(c) The Author(s), under exclusive licence to Springer Nature Switzerland AG 2022

\begin{abstract}
Because of the threat that Covid-19 poses to incarcerated populations, executives around the world have used their clemency powers to commute sentences and grant freedom to prisoners in high-risk categories. Coronavirus pardons may be justified on several theories of punishment and have been exercised alongside bureaucratic forms of legal mercy such as parole and compassionate release. Although executive clemency is residual in most legal systems, the novel coronavirus has reactivated the pardon power in many jurisdictions, overcoming significant legal and procedural barriers, albeit with exclusions for particular crimes and categories of offender. This article relays recent global trends in executive clemency granted as a result of Covid-19, drawing out relevant lessons for the academic literature on the topic, as well as for policymakers dealing with future pandemics and other emergencies.
\end{abstract}

Keywords Clemency $\cdot$ Coronavirus $\cdot$ Covid-19 $\cdot$ Executive clemency $\cdot$ Mercy $\cdot$ Pardon $\cdot$ Prerogative of mercy $\cdot$ Prisons

\section{Introduction}

The novel coronavirus, Covid-19, poses a significant threat to incarcerated persons: the virus is airborne and typically requires person-to-person transmission through the respiratory system. It spreads particularly easily in overcrowded and unsanitary living quarters. However, responses by prisons and prison guards have sometimes been clumsy, even extending to placing those who are symptomatic in solitary confinement, or to shifting prisoners between cell blocks or institutions (Kinner et al., 2020, p. E188; Widra \& Havre, 2020). Reducing prisoner numbers is the more direct means of dealing with the virus' urgent threat. As such, many jurisdictions around the world have activated executive clemency powers alongside other decarceration measures such as legislative amnesty, parole, or compassionate release, in an effort to reduce the risk of cross-infection. During the

Andrew Novak

anovak2@gmu.edu

Daniel Pascoe

dcpascoe@cityu.edu.hk

1 Department of Criminology Law and Society, George Mason University, Fairfax, USA

2 School of Law, City University of Hong Kong, Kowloon Tong, Hong Kong pandemic's early stages between March and June 2020, London-based NGO Harm Reduction International estimated that at least 109 countries freed prisoners as a direct result of the coronavirus. Many of these released prisoners benefited from an executive-sourced pardon or commutation power, or at least a temporary respite from imprisonment (Harm Reduction International, 2020). The result is an unprecedented and creative use of executive clemency, which we reflect on in this article.

Although the data we present below are largely anecdotal rather than empirical, deriving primarily from recent news media and NGO reports, the vast breadth of reporting on coronavirus clemency enables us to pinpoint and analyse the key global trends. After initially outlining the moral, legal and political case for coronavirus clemency in Part II, below we reflect on the unprecedented use of mass clemency as a release mechanism during the ongoing pandemic (Part III), the way that some executive actors have overcome previously troublesome legal and bureaucratic obstacles to granting clemency (Part IV), various restrictions on the classes of persons receiving coronavirus clemency (Part V), and the relationship between executive clemency and other discretionary release mechanisms in this context (Part VI). We conclude in Part VII with Covid-19's impact on the academic literature on executive clemency, and with policy 
lessons for chief executives arising from the recent upsurge in pardons and commutations.

\section{The Case for Coronavirus Clemency}

Clemency is an extraordinary remedy by which a political executive can modify or cancel a criminal sentence (Novak, 2016a). Although clemency is residual in many developed legal systems, replaced by bureaucratic processes including parole, remission or early release, its use in the developing world and in autocratic systems is still pronounced (Novak, 2016b; Pascoe \& Novak, 2020a; Pascoe, 2019b). In the United Kingdom, the Queen's prerogative of mercy at common law has become strictly limited by convention. It is now used only in the most unusual circumstances to correct historic injustices such as to pardon the 'shellshock' deserters of World War I, gay men prosecuted under anti-sodomy laws, or battered women who were wrongly punished for murder (Cooper \& Burrows, 2020; Seal, 2014; Wessely, 2006). In most other countries, however, written constitutions define the scope of the clemency power, thereby endorsing its (at least occasional) use for legal and political reasons (Pascoe \& Novak, 2020b).

Because executive clemency is potentially subject to misuse for arbitrariness or self-dealing, the discretion of the clemency authority is frequently limited in at least one of three ways. The first is involvement of some other actor in the decision-making process, typically a politically accountable actor or an 'expert' (Novak, 2016b). ${ }^{1}$ The second is provision for transparency or review after the fact by a legislative, judicial, or administrative actor. ${ }^{2}$ Finally, executive clemency is pockmarked with exclusions that restrict the discretion of the executive in specific types of cases (Novak, 2016b). Through these mechanisms, many jurisdictions around the world have reconciled two competing values:

\footnotetext{
1 A nonpolitical executive such as a governor-general or an indirectly elected president may require approval from a prime minister or minister of justice. In other jurisdictions, the Cabinet or an advisory committee on the prerogative of mercy may make the recommendation. The membership of these committees may include, for instance, doctors, corrections officials, or prosecutors.

${ }^{2}$ In some common law countries, the prerogative of mercy has opened to judicial review in some circumstances. See Queen v Secretary of State for the Home Department [Ex Parte Bentley] [1993] EWHC Admin 2 (7 July 1993); Lewis v Attorney General of Jamaica [2000] UKPC 35; Maru Ram v Union of India (1978) 2 SCR 621. In the United States and Australia, freedom of information laws have been applied to the clemency decision-making process. See Judicial Watch, Inc v US Department of Justice (2004) 365 F3d 1108 (DC Cir); Osland v Secretary to the Department of Justice [2010] HCA 24. In French-speaking West Africa and certain other jurisdictions (such as Iran, Finland and Paraguay), a judge, a court, or a judicial commission must advise on or ratify a grant of clemency (Pascoe \& Novak, 2020a).
}

the desire for a 'safety valve' that can prevent overly harsh sentences and the ever-present risk of executive misuse of the pardon power.

Virtually all legal systems have provision for executive clemency in law. As of 2018, at least 183 national constitutions provided a clemency process and most of the remainder possessed either a clemency process defined by unwritten convention or by statute (Pascoe \& Novak, 2020a; Pascoe \& Novak, 2020b). Clemency is still relevant in so many jurisdictions because it simultaneously serves several different criminal justice purposes: it can be redemptive, retributive, and utilitarian (Cooper \& Gough, 2014). ${ }^{3}$ Clemency can forgive or express benevolence; it is a safety valve for wrongful convictions or overly harsh sentences; and it can reduce the costs of incarceration (Barkow, 2009; Minow, 2019).

We propose that coronavirus clemency, whether in the shape of pardons (in this context, immediately releasing a prisoner and ending the sentence), commutations (a permanent reduction of penalty), respites (a pause in the sentence) or reprieves (delaying the execution of the sentence), can be justified on at least three different moral grounds, consistent with the previous literature on clemency rationales (Novak, 2016a). Most obviously, because such grants can stop community spread of coronavirus by reducing the dangers posed by overcrowding, clemency in this instance would arguably serve the utilitarian benefit for the greater good (Kobil, 2003). ${ }^{4}$ We acknowledge that the utilitarian rationale could also work the other way, especially if a disease outbreak occurs in the correctional facility. According to this argument, early release of ill or at-risk prisoners could directly contribute to community spread. However, since coronavirus must be spread from the community into the prison in the first instance, the utilitarian rationale favours early release before an outbreak takes place. In addition, since corrections staff are more likely than prisoners to bring the virus in and out of the facility due to their greater mobility, the risk of transmission from inside the prison to the surrounding community exists even where no early release occurs (Nowotny et al., 2021). From a utilitarian perspective, early release for vulnerable prisoners is more likely to curtail rather than contribute to the spread of coronavirus.

\footnotetext{
${ }^{3}$ Clemency may also be granted to boost the popularity or perceived religiosity of a national leader, but this paradigm is less relevant to coronavirus clemency (Pascoe, 2019b).

${ }^{4}$ In the near future, we may even see pardons or commutations as a utilitarian 'reward' for prisoners agreeing to be vaccinated against Covid-19, echoing a now-discredited early twentieth century smallpox 'variolation' trial (Dudgeon, 1980). In the United States, several jurisdictions are experimenting with good time credits for prisoners who accept a vaccine, amounting to between five and seven days of early release (Associated Press, 30 January 2021; CBSBoston, 3 February 2021).
} 
Coronavirus clemency can also serve a retributive rationale. Releases can prevent overly or unexpectedly harsh punishment; incarcerated persons do not deserve to face preventable conditions that threaten their health and lives. Here, we propose that such clemency grants are justified on retributive grounds because they prevent an undeserved outcome, especially if grants are tailored to the prisoners who face the greatest health risks or who are serving the lightest sentences (Moore, 1989). Custody-based alternatives to combat the spread of Covid-19 such as isolation from other prisoners will also serve to impose undeserved punishment on inmates. Inaction by prison officials and justice ministries even poses legal and constitutional risks that clemency could help mitigate. The United Nations and human rights NGOs have cautioned that unjustified exposure to Covid19 could constitute 'cruel and degrading treatment', especially if prisoners received substandard medical care, were placed in solitary confinement to reduce spread of disease, or suffered other rights deprivations during a 'lockdown' (Lachsz \& Hurley, 2021; World Health Organization, 2020). In the United States, one California state judge found prison officials may have violated prisoners' constitutional rights against 'cruel and unusual' punishment by failing to reduce the incarcerated population at San Quentin State Prison before an outbreak occurred (CBS San Francisco, 2021, 18 November, citing In the Matter of Hall et al., San Quentin Consolidated Writ Proceeding, Marin County Superior Court, 2021, 16 November.).

Finally, we propose that coronavirus-related clemency can also be consistent with a rehabilitative or restorative outcome, if it is granted as a 'reward' to rehabilitated offenders nearing the end of their sentences or if the grant is conditional on law-abiding behaviour or service (either before entering prison, or out in the community upon release). As a policy response to Covid-19, clemency can be faster than other bureaucratic forms of early release and broader in its eligibility, eschewing the procedures or waiting periods of parole, remission, or compassionate release (e.g., Thomas, 2012). It is also a more immediate response than a legislative amnesty, which at least in democratic systems would require extensive parliamentary debate and compromise among different interest groups (Pascoe, 2019a). Discerning the justification for a specific instance of clemency may be difficult (Acker et al., 2010; Kobil, 1991). However, the rationales for coronavirus clemency-utilitarian, retributive, and rehabilitative - are not mutually exclusive. Part of clemency's durability throughout modern political history has been its ability to serve multiple motivations simultaneously and reconcile tensions among conflicting interests.

Historically, clemency for individual illness or medical vulnerabilities has been routine, especially for life-threatening or terminal conditions (Kobil, 1991; Love, 2001). There are several early precedents from the United States. During the late nineteenth century, prisoners suffering from serious infectious diseases in US prisons were routinely released, along with those too ill to be cared for (Love, 2001). This was especially true in the case of contagious illness. In Florida, one prisoner with consumption received a conditional pardon in 1914 for fear that she would 'endanger the health of other prisoners'; in 1917, another prisoner with tuberculosis was also deemed a menace to other prisoners (Miller, 1998). During the Spanish flu pandemic in 1918, incarcerated soldiers in Boston and San Francisco who volunteered to be exposed to influenza for public health studies received full pardons (Gernhart, 1999). In 1927, Barnett wrote that 'prisoners infected with contagious diseases' had been released in the recent past (Barnett, 1926-1927).

Nevertheless, whether in the US or elsewhere, we have found few examples of policy-based mass clemency grants to specifically prevent disease transmission in the carceral context, or in situations where corrections staff could contribute to community spread. During the Black Death, Danish King Valdemar (1320-1375) pardoned all death row prisoners due to the depopulation caused by the plague (Høiby, 2020). Although the ultimate motivation was not public health related, the Danish pardon was a utilitarian categorical pardon. In the Canadian province of Manitoba, First Nations and Métis participants in the North-West Rebellion in 1885 were incarcerated in overcrowded conditions where they were susceptible to respiratory disease, leading to several significant pardon grants (McCoy, 2009). Following the 1980s-1990s HIV/AIDS epidemic, a prisoner's HIV status or risk of contracting HIV in prison can be possible grounds for executive clemency in a variety of jurisdictions (Anderson, 1989). In the US state of Georgia, for instance, state law specifically provides that HIV test results may be considered in decisions for pardon, clemency, or parole. ${ }^{5}$ The difference in these cases is that the releases granted were primarily aimed at reducing the suffering of afflicted or acutely vulnerable prisoners, or to reintegrate prisoners as economically useful members of society, rather than slowing the broader community spread of a highly infectious disease.

In practice, clemency is largely residual in most modern legal systems. However, the executive power to commute or pardon has always evolved with prevailing social contexts. During the Covid-19 pandemic, some observers have noted that executive clemency remains an imperfect tool for the mass release of prisoners. Writing on the US context, Kovarsky notes that the 'clemency structure is not nearly as nimble as some imagine' in situations of urgency

\footnotetext{
${ }^{5}$ Georgia Code Sect. 42-9-42.1 (2017). This provision also authorizes the Georgia State Board of Pardons and Paroles to grant conditional pardon, where the conditions are designed to prevent the spread of HIV.
} 
such as Covid-19, as both the federal regulations and many state constitutions require administrative or board review that implicitly create 'subtle multiple-veto problems that prevent speedy, broad discharge' (Kovarsky, 2020). He also points to the original purposes of clemency as limited to circumstances of retribution or political settlement, rather than to stop the spread of disease (Kovarsky, 2020).

We propose, however, that a global perspective shows that many jurisdictions, including some US states, have already creatively and urgently used the clemency power to protect prisoners and stop community spread. Mass clemency in the context of Covid-19 is novel, but it is not entirely unprecedented and is consistent with a historical conception of clemency that allowed for the possibility of utilitarianbased mass pardons. Some recent scholarship has promoted executive clemency as a policy tool to combat the spread of disease (Drinan, 2011; Fox, 1999; Kobil, 1991), in contrast to earlier historical eras when pardon was more frequently granted but primarily justified as a benevolent tool to bolster executive power (Strange, 1996). The following four sections will demonstrate the ways in which the Covid-19 pandemic has renewed and expanded the practice of executive clemency around the world, largely in line with the recommendations of such pre-pandemic scholarship.

\section{The Unprecedented Scale of Mass Clemency During the Pandemic}

Already by the time of writing in December 2020, Covid-19 has altered clemency law and practice in many jurisdictions across the globe. Once-reluctant executives have embraced the pardon power and issued mass pardons. Legal, conventional or constitutional obstacles to granting clemency have been lowered. While many collective pardons and subsequent releases from prison have been permanent, an unusually large number have been temporary for a period of weeks or months, and hence mere 'respites' from punishment (Harm Reduction International, 2020). Overall, the pandemic shows that executive clemency's flexibility is a key reason why it remains relevant, as a legal device, within the modern constitutional scheme.

Some jurisdictions have already relied heavily on mass pardons or commutations to reduce the risk of coronavirus spread in prison. In March 2020, President Ashraf Ghani of Afghanistan announced that he would shortly release around 10,000 prisoners to slow the spread of coronavirus, albeit excluding Taliban and Islamic State militants (Sediqi \& Shalizi, 26 March 2020; SNS Web, 27 March 2020). The following month, a further 12,000 prisoners enjoyed the same outcome (Khan, 27 April 2020). On 5 April, King Mohammed VI of Morocco pardoned 5654 detainees using criteria based on age, health, conduct, and length of detention
(Middle East Eye, 5 April 2020). In Uganda, President Yoweri Museveni pardoned 833 prisoners on 28 April, out of more than 2000 that the nation's prisons service recommended to the Advisory Committee on the Prerogative of Mercy (Uganda Radio Network, 28 April 2020). In Ghana, President Nana Akufo-Addo has historically been unmerciful; his immediate predecessor John Dramani Mahama granted at least four mass pardons on Republic Day in July every year while Akufo-Addo granted none since taking office (Inusah, 7 November 2018). Since the onset of the pandemic, however, Akufo-Addo issued a mass pardon for 808 prisoners on 26 March 2020 and another pardon of 794 on 2 July (Joy Online, 26 March 2020; GhanaWeb, 2 July 2020). President Mokgweetski Masisi of Botswana pardoned 149 prisoners on 15 April 2020, of whom 96 were incarcerated and 53 were serving extramural labour. Twenty of those were foreign nationals (Ngatane, 17 April 2020). This was President Masisi's first use of his prerogative of mercy. Several jurisdictions issued more than one mass clemency grant within a relatively short timeframe, including the UAE (ICF UAE, 27 July 2020), Zimbabwe (Maphosa, 6 May 2020), and, as mentioned, Ghana and Afghanistan.

Existing prison overcapacity overwhelmingly motivated several other mass pardons, a policy approach urged by the United Nations High Commissioner for Refugees (Diamoutene, 6 April 2020). ${ }^{6}$ In Malawi, President Lazarus Chakwera pardoned 499 inmates on 14 August 2020, but also reduced the sentences of every prisoner in Malawi by six months to gradually reduce prison congestion (Masina, 15 August 2020). President Paul Biya of Cameroon issued a staggered mass pardon, which reduced death sentences to life, life sentences to 25 years, 25 -year sentences to 20 years, 10-year sentences to seven years, and so on (Kindzeka, 16 April 2020). According to World Prison Brief data, at the time of writing, Malawi's prisons are at 200 percent capacity and Cameroon's are at 174 percent capacity (see World Prison Brief, https://www.prisonstudies.org/world-prisonbrief-data). In Mozambique, the nation's colonial-era prisons, with an 8000 person capacity, held 21,000 prisoners before a mass grant of presidential pardon reduced the discrepancy (Club of Mozambique News, 8 April 2020; Club

\footnotetext{
${ }^{6}$ Other UN agencies to recommend decarceration during the pandemic include the UN High Commissioner for Human Rights and the UN Subcommittee on the Prevention of Torture (see Human Rights Watch, 2020). Human Rights Watch has recommended that the following categories of persons be released:

those held for minor offenses... those nearing the end of their sentence... those hailed for technical violations of probation or parole... incarcerated children, older, and otherwise medically vulnerable people, and people who are caregivers to vulnerable people... detainees who have not been charged... detainees held in pretrial detention, unless they pose a serious and concrete risk to others. (Human Rights Watch, 2020).
} 
of Mozambique News, 17 December 2020). In Bolivia, prison capacity reached 364 percent, before the government announced plans to halve convict numbers through pardons (Harm Reduction International, 2020).

In some countries, mass pardons have been framed as benevolent grants of mercy, coinciding with national or religious holidays. For example, in March 2020 during the Iranian New Year (Nowruz), Iran afforded 85,000 prisoners temporary release, whereas Ayatollah Ali Khamenei permanently pardoned 10,000 others. When combined, these releases benefited approximately a third of the country's prison population (Shelton, 19 March 2020). In April 2020, President Win Myint of Myanmar similarly used the nation's traditional New Year holiday (Thingyan) as an occasion for an unusually large mass pardon of nearly 25,000 inmates, including 87 foreign nationals (ABC News, 17 April 2020). Also in April, amid a surge of Covid-19 cases, the President of the UAE, Sheikh Khalifa bin Zayed Al Nahyan, released 1511 prisoners in the lead up to the Muslim Holy Month of Ramadan (Hilton, 22 April 2020; Nasrallah, 21 April 2020; Emirates News Agency, 21 April 2020). The academic literature on clemency suggests that autocratic chief executives typically use this kind of clemency grant to boost their perceived religiosity, benevolence, and ultimate legitimacy before domestic constituents and foreign governments (Pascoe, 2019b). Yet, in each case described, the unusually large size of the mass pardon was ultimately precipitated by the Covid-19 pandemic.

\section{Overcoming Legal and Bureaucratic Barriers to Clemency}

The urgency of the coronavirus threat to incarcerated populations has also motivated executives to overcome ordinary legal and bureaucratic barriers to granting clemency. For example, in Somalia, President Mohamed Farmaajo pardoned 148 prisoners for petty crimes on 2 April 2020 (Xinhua, 2 April 2020). Article 90(p) of Somalia's Constitution allows the president to pardon with the recommendation of the Judicial Service Commission. It appears the Somali president pardoned only petty rather than serious crimes in order to evade this requirement and reduce prison numbers in the speediest way possible. In Michigan, one inmate infected with Covid-19 received an 'expedited hearing' before the Michigan Parole Board when the state attorney general advocated on his behalf in a letter to Governor Gretchen Whitmer. The prisoner had been ineligible for parole and hence a commutation from Governor Whitmer formed the most immediate option for release (van Wagtendonk, 15 August 2020). Among US states, Oklahoma went even further: the Oklahoma Pardon and Parole Board prioritised inmates who were scheduled for release within
12 to 18 months. Applications by inmates facing heightened medical risk were also accelerated (Trotter, 13 April 2020). Under these protocols, Oklahoma Governor Kevin Stitt commuted 452 sentences on 16 April 2020 (Raache, 10 April 2020). In another example, the Philippines Department of Justice approved simpler rules for faster processing of both parole and clemency requests, which removed most of the paperwork requirements. Prisoners over age 65 and those with pre-existing medical conditions could use the new process, but the latter group required a medical certification (CNN Philippines, 22 April 2020). Some executives have even used their clemency powers beyond the scope authorised by law in response to the pandemic. In Haiti, President Jovenel Moïse granted a mass pardon to 415 prisoners on 19 June 2020. Though Article 146 of the 1987 Constitution of Haiti explicitly prevents pardons before conviction, news reports indicated that Moïse granted at least one pardon to an accused murderer awaiting trial (Charles, 1 July 2020).

Many constitutions authorise or require an executive decision-maker to consult with a pardons board or advisory mercy committee. In contrast to what occurred in Somalia, some executives have appointed or reactivated such committees specifically to advise on coronavirus pardons. For example, the Constitution of Nigeria 1999 at Article 212(2) requires state governors to consult with an advisory council on the prerogative of mercy to grant pardons under state law. After granting his own mass pardon to 2600 prisoners, Nigerian President Muhammadu Buhari urged state chief justices to visit prisons and release inmates to prevent coronavirus spread (Asadu, 21 April 2020; Osuyi, 26 April 2020). Subsequently, the Kwara state governor appointed a Prerogative Advisory Council to urgently consider release for persons with minor convictions, women with children, and convicted persons who completed 75 percent of their sentences, among others (Adebayo, 15 April 2020). In Ekiti State, the governor convened an emergency meeting of the Advisory Council on the Prerogative of Mercy and suspended its normal rules, in order that it would prioritise vulnerable prisoners or those nearing the end of their sentences (Vanguard, 16 April 2020). In Abia State, the Attorney General did likewise, organising a committee meeting to advise Governor Okezie Ikpeazu on coronavirus pardons (Nwankwo, 5 May 2020).

In some US states, ordinary procedural barriers to granting clemency are significant. Twenty-four states expressly permit public hearings for pardon applicants, ten of which specifically require the applicant's presence in-person (Dorne \& Gewerthe, 1999). Quarantine and social distancing rules prompted some creativity in complying with these restrictions. In Utah, Governor Gary Herbert issued an executive order on 17 March 2020, suspending the rules requiring public viewing of the Board of Pardons meetings and authorising electronic access. Herbert allowed in-person pardon hearings that were restricted to the applicant, 
counsel, a board member, each victim, victims' representatives and family members, and a representative from the police or prosecutor's office (Utah Executive Order 2020-3, suspending Utah Administrative Code R671-302). Completely online hearings are another option. In Pennsylvania, the Board of Pardons must conduct in-person interviews with current inmates seeking commutations and must hold in-person public hearings. Such restrictions apparently frustrated efforts to move forward on clemency requests as the June 2020 hearings were cancelled (ABC27, 28 April 2020). In August 2020, the Board of Pardons made an 'unprecedented' move to schedule clemency hearings online, both for pardon applicants and for currently incarcerated inmates seeking commutations (Abrams, 19 August 2020). Other states allowed for an expanded review of written statements to replace in-person hearings. For example, the Alabama Bureau of Pardons allowed officials, family members, crime victims, and other interested parties to make statements by post, email, or phone (Hodgin, 13 April 2020).

However, some jurisdictions have made no progress at all, either because of institutional barriers or penal populism (Godfrey \& Rovner, 2020). In the Philippines, the regulation change designed to speed up clemency applications encountered a procedural hurdle: a waiting period for rules changes. The Supreme Court required the Department of Justice to observe the 15-day waiting period before the new rules could take effect (Pazzibugan, 1 May 2020). In some parts of the US, the barriers were even greater. Massachusetts has an unusually burdensome clemency process, as the governor requires approval of both the appointed Advisory Board of Pardons and the elected Governor's Council (Wolfe, 2007). A Boston Globe editorial condemned the 'dysfunction and delay' that put inmates at greater coronavirus risk and the Supreme Judicial Court urged the governor to use his executive powers (Boston Globe, 13 August 2020). In Louisiana, Governor John Bel Edwards stalled a recommendation for clemency from the state's Board of Pardons even though the applicant was hospitalized with coronavirus. This was but one of roughly 200 inmates with positive recommendations from the Board, with no action by the governor (Skene, 22 April 2020). Since many executives do not have to provide reasons for their clemency or pardons, we cannot know their motivations for certain. In March 2020, California Governor Gavin Newsom granted five pardons and 21 commutations, indicating that coronavirus factored into his decisions; however, media reports identified other reasons for these clemency grants, including rehabilitation, juvenile status, or deportation risk (Wiley, 27 March 2020). While the total prison population in the US fell by eight percentage points during the early months of the pandemic, this is primarily explainable by fewer prison admissions, rather than due to a concerted effort by state and federal executives to scale back existing mass incarceration (Sharma et al., 16 July 2020). As of May 2020, according to The Intercept, 'restrictive criteria and bureaucratic hurdles have meant that [pardon and parole] releases, where they have actually happened, have made no significant dent in what continues to be a sprawling mass incarceration apparatus' in the United States (Speri, 14 May 2020).

\section{Defining Who is Eligible for Clemency}

Where legal and bureaucratic burdens have not prevented individual or mass grants of clemency, jurisdictions nonetheless vary as to which prisoners are eligible for clemency because of the coronavirus threat. The most common profile for prisoners who have so far benefited from mass pardons or commutations are those who are aged or in poor health, women (particularly women caring for young children), those awaiting trial, those near the end of their sentences, or those serving short sentences (Human Rights Watch, 2020). ${ }^{7}$ In this sense, coronavirus clemency's criteria does not differ greatly from criteria typically employed outside of the pandemic (Pascoe 2019b; Pascoe \& Novak 2020a). It is merely that Covid-19 has made such decisions more urgent.

For example, in Afghanistan, President Ghani's pandemic-induced mass pardon focused on prisoners with serious health problems, women, children, and persons over age 55 (Sediqi \& Shalizi, 26 March 2020). In Nigeria, the Federal Government's mass pardon benefited inmates age 60 and above, those suffering from ill health, those serving at least three years with less than six months remaining, and those with mental illness (Asadu, 9 April 2020). A Nigerian state-based pardon in Gombe State also extended to young offenders aged under 16 (Michael, 30 April 2020). In Uganda, the list of pardoned prisoners extended to those who have completed three-quarters of their sentences, breast-feeding women and prisoners over 60 years old (Daily Monitor, 28 April 2020). In Bolivia, a clemency grant benefiting both suspects on remand and convicted prisoners applied to detainees over 58 years old, those suffering from terminal illness, women who were pregnant, and prisoners caring for children under six years of age (Cuiza, 18 May 2020). Many countries first looked to release prisoners based on the length of sentence remaining, which in Harm Reduction International's estimation ranged from two months remaining in Côte d'Ivoire to three years in Albania (Harm Reduction International, 2020). In Abia State, Nigeria, the

\footnotetext{
${ }^{7}$ Harm Reduction International's compilation of prison decongestion efforts around the world (by all procedures, including clemency) shows that the most common eligibility criteria limited beneficiary groups to juveniles, pregnant women, detainees with health conditions, elderly persons (defined variously as $55+$ and $75+$ years old), and persons awaiting trial (Harm Reduction International, 2020).
} 
eligibility criteria even extended to prisoners who had up to four years remaining on their sentences, with anything less being 'almost served out', making the prisoner eligible (Nwankwo, 5 May 2020).

Some jurisdictions have carved out exceptions for certain types of prisoners, most commonly violent, drug and sex offenders. Again, clemency restrictions and criteria of this nature were not unusual before the pandemic, both within legislation and constitutional provisions, as with actual practice (Pascoe, 2019b; Novak, 2016c; Pascoe \& Novak, 2020b; Laird, 2017). Nonetheless, whether arising after Covid-19 or not, blanket clemency exceptions predicated upon crime categories are problematic because they may well be driven more by penal populism or intolerance of political dissent rather than by the risk of reoffending. For example, Algerian President Abdelmadjid Tebboune exempted terrorism, state security crimes, murder, rape, and drug crimes, among others, from a mass pardon of 5037 prisoners prompted by Covid-19 (Jibril, 1 April 2020). After prisoners convicted of 'murder, robbery, car-jacking, sexual offences and public violence' were excluded from a mass grant of presidential clemency in Zimbabwe in March 2020, the grant fell two-thirds short of the Zimbabwe Prisons and Correctional Services target of 5000 releases (Maphosa, 2 April 2020). However, in May 2020, President Emmerson Mnangagwa issued an extension of the preceding mass clemency order to benefit juveniles, bed-ridden prisoners, blind prisoners, disabled prisoners, and those who had served at least 20 years of a life or a death sentence. While the amended order still exempted violent crimes, previously excluded prisoners who otherwise fell within the clemency extension could now qualify for clemency (Zimeye, 1 May 2020). The Cameroonian mass pardon excluded prisoners convicted of serious offences such as 'terrorism, misappropriation of State property, tax fraud, customs fraud, sexual offences or ... security' offences (AllAfrica, 28 April 2020). The Bolivian amnesty and pardon grants exempted 'persons prosecuted for serious crimes, such as rape, human trafficking, femicide, murder, kidnapping or smuggling, and repeat offenders', but unusually, there were no exclusions for drug traffickers (Cuiza, 18 May 2020). In Peru, a decree by President Martín Vizcarra creating a new 'humanitarian pardon' procedure contained many exclusions, such as for corruption, sex-related crimes, violent crimes, crimes against the state, national security offenses, terrorism, and crimes against humanity. Finally, Harm Reduction International (2020) reports that drug offenders have been excluded from prison decongestion efforts, which include executive clemency, in at least 28 different countries.

In other jurisdictions, mass clemency grants did not include political prisoners or prisoners of conscience. President Paul Biya of Cameroon excluded political prisoners from a mass commutation, among them opposition politicians and separatists fighting for autonomy for the English-speaking region of the country (Kindzeka, 16 April 2020). The King of Bahrain evidently deliberately excluded prominent political prisoners in a mass pardon of 901 inmates, including Arab Spring protestors and Shia clerics (Alshammari, 24 April 2020). In Iran, despite nearly 100,000 prisoners being released during the first half of 2020, violent offenders and detainees involved in 'security cases' remained incarcerated (Hafezi, 19 March 2020). The Iranian state believes that these convicts still 'pose a danger to society' (Hashmi, 14 July 2020).

We also observe a trend of excluding prisoners convicted for serious international crimes. Chile, like Peru, also excluded from its mass amnesty scheme those who were convicted of crimes against humanity during the country's period of military dictatorship. While President Sebastian Pinera pardoned 1300 prisoners who were most at-risk of coronavirus, nearly 100 prisoners convicted of human rights violations during the Augusto Pinochet dictatorship (1973-1990) were not included (Straits Times, 15 April 2020). Controversially, however, a Senegalese court provided 78-year-old former Chadian President Hissène Habré with 60 days of house arrest as a 'respite' from his life sentence in prison for crimes against humanity (Petesch, 7 April 2020). While this decision was not an exercise of executive clemency per se, it highlights the values clash between release of vulnerable prisoners and impunity for human rights abuses. Habré returned to prison after the 60 days lapsed (AfricaNews, 7 June 2020). The exclusion of clemency for serious international crimes is part of a broader global trend toward accountability for human rights abuses, defined by Sikkink (2011) as the 'justice cascade'. An increasing number of new constitutions specifically exclude serious international crimes and other gross human rights violations from the scope of executive clemency (Novak \& Pascoe, 2020).

Exceptions such as those described above may not only be unjustifiable because of an undifferentiated risk of recidivism, but also because continued detention has the potential to exacerbate the punishment initially imposed through sentencing, by exposing these prisoners to the risk of illness and death through Covid-19. Where a prison population must be rapidly and substantially reduced, if we assume that the length of a determinate prison sentence is roughly proportionate to the (perceived) gravity of the offence, then aside from physical vulnerability to the virus, the fairest criteria to determine eligibility for release must surely be the length of time remaining to be served, with no exclusions for particular offences. If the relevant executive decision-maker wishes to further weigh the risk of recidivism, then even much-debated predictive tools and algorithms stand to result 
in fairer outcomes than crude approximations on the basis of the offence committed (Christin, 2018). ${ }^{8}$

\section{Clemency and Other Release Mechanisms}

Finally, we consider clemency's relationship to pandemicinduced releases via other procedural methods, which can include the dropping of charges by police or prosecutors, releases by judicial order, parole, remissions, legislative amnesty, and compassionate release, among other methods. Clemency is far from the only means through which national and provincial governments have lowered incarceration to slow the spread of Covid-19, although as noted above, pardons, commutations or respites are among the most efficient mechanisms for this purpose, given that their use tends to attract relatively little legislative, administrative, and judicial oversight. For those bureaucratic obstacles that do exist, above we have mentioned some of the creative ways that executives have recently circumvented these. In one sense, if a government's sole aim is to reduce the spread of Covid19 , the procedural method by which prisoner populations are reduced is irrelevant. However, the precise mechanisms chosen by the executive, legislative and judicial branches reveal much about the legal limits of the clemency power in situations of emergency, and about which actors ought to bear the political risk for early releases from prison (Kovarsky, 2020).

Sometimes executive clemency has been combined with other methods of leniency in a single jurisdiction. In jurisdictions where prison overcrowding is caused by both pre-trial and post-conviction detention, judicial mechanisms such as bail have often been employed to deal with the former, whereas executive clemency has been used to reduce the latter. Conditional bail has the advantage of greater oversight over released suspects, when compared with unconditional executive clemency or legislative amnesty. Several examples are as follows. In Gombe State, Nigeria, magistrates and judges released more than 115 inmates who were then awaiting trial in April 2020, whereas the State Governor pardoned 28 prisoners who had already been convicted (Michael, 30 April 2020). In Nigeria as a whole, while 2600 prisoners received pardon from President Muhammadu Buhari, more than 1000 remand prisoners also received bail from state Chief Judges (Adepegba, 21 May 2020). In Zambia, 2984 convicted prisoners have been granted pardon whereas 2000 pre-trial detainees have also received unconditional bail (Harm Reduction International, 2020). In Sri Lanka, a proposal for a group pardon by President Gotabaya Rajapaksa was accompanied by a state offer to pay minor bail sums

\footnotetext{
${ }^{8}$ On the effectiveness and scientific validity of risk assessment tools, see further Taxman ed. (2017).
}

to release suspects from pre-trial detention (AdaDerana, 8 December 2020). In the immediate future, this combination of release mechanisms (bail and clemency) may prove particularly useful in jurisdictions, such as the United Kingdom, Haiti, Chile, and Panama where the executive's prerogative power traditionally only extends to releasing convicted offenders (Pascoe \& Novak, 2020b).

In jurisdictions with significant procedural hurdles or where penal populism constrained the executive, clemency has been sidelined, while other forms of early release appear more politically acceptable. In New York State, during the pandemic's early months Governor Andrew Cuomo granted only a handful of pardons and sentence commutations, none explicitly for coronavirus-related reasons, despite an intense campaign by criminal justice reform activists and families of incarcerated people (Slattery, 22 September 2020). Yet, by June 2020, the Department of Corrections and Community Supervision announced that 1861 individuals had benefited from early release, including 791 people on parole; 1062 in confinement but within 90 days of release; and eight pregnant or postpartum women within 180 days of release (New York State Governor's Office, 17 June 2020). In the Philippines, the 'tough on crime' president, Rodrigo Duterte, granted only one absolute pardon between January and November 2020, whereas 1333 prisoners were granted parole during the same period, following a relaxation of parole eligibility requirements. The 35 percent annual increase in parolees during 2020 was specifically intended to help curb the spread of Covid-19 in Philippine prisons (Philippine Daily Inquirer, 2 January 2021; Business World, 17 August 2020). A similar liberalization in eligibility rules for executive clemency has evidently failed to have any effect, presumably due to the political liabilities that pardons would create for President Duterte.

In Peru, the conservative president, Martín Vizcarra, faced nationwide prison riots throughout April 2020 over his reluctance to grant clemency after several inmates died of Covid-19 (Bangkok Post, 29 April 2020). In the most serious prison riot, nine inmates were killed (Reuters, 28 April 2020). In a speech on 29 April, President Vizcarra insisted that he would not pardon corrupt or violent offenders, and specifically complained that his predecessors had pardoned drug traffickers (Andina, 29 April 2020). Instead, Vizcarra created a new form of executive clemency by decree, known as a humanitarian pardon ('indulto humanitario'), for prisoners who were vulnerable to the virus. Under the temporary 'indulto humanitario' procedure, the Presidential Grace Commission considered the medical history of vulnerable prisoners, a procedure which was not required for regular pardons and commutations. Nonetheless, in part because of his mishandling of the Covid-19 pandemic, Vizcarra was ultimately impeached twice and removed from office in November 2020 (Briceño \& Armario, 10 November 2020). 
Other combinations of discretionary tools have enabled governments to pursue complementary policy objectives, alongside reducing incarceration levels to slow the spread of disease. An April 2020 report revealed that temporary parole had already released prisoners in Kerala State, India, whereas executive clemency would later be used to (permanently) confirm the freedom of the most well-behaved parolees (Sudhi, 7 April 2020). Returning to Peru, President Vizcarra granted common pardons ('indulto comón') and commutations alongside his new category of humanitarian pardons. However, these common pardons were limited to mothers of children under three, persons with sentences shorter than four years, persons over 70 years of age, persons with six months or less remaining on their sentences; humanitarian pardons were primarily for prisoners with pre-existing medical conditions as these required a medical report. A total of 1502 prisoners were released from Peruvian prisons by June 2020, including 307 'humanitarian pardons', 278 sentence commutations, 29 'common pardons', and 39 juvenile pardons. This number also included those who benefited from two other discretionary releases: 989 prisoners who were imprisoned for failure to pay child support had their sentences converted to maintenance orders, and 167 prisoners had custodial sentences converted to non-custodial ones or were released from pretrial detention (Gobierno del Perú, 13 June 2020). In Tunisia, among more than 2000 pandemic-related releases, some prisoners were pardoned entirely whereas others were transferred to home detention to serve their sentences (Harm Reduction International, 2020). In cases such as these (Kerala, Peru, and Tunisia), it appears that an exclusive reliance on blanket executive clemency grants (particularly in the form of release by pardon) would not serve to maintain incapacitative measures against the most dangerous prisoners, sufficiently incentivise good behaviour upon release, contribute to the restoration of harms suffered by victims, or indeed, maintain political popularity. Accordingly, executive clemency was only part of a package of measures used to swiftly deal with a complex criminal justice problem.

\section{Conclusion: A Novel Clemency Paradigm?}

Covid-19 has certainly stimulated the use of executive clemency, in addition to other methods of discretionary leniency, in an 'unprecedented' manner, to repeat an adjective overused during the pandemic. Yet, do the sum of these releases amount to a new clemency paradigm entirely? Although we are not aware of any grants of executive clemency specifically made to slow the community spread of infectious disease over the past several decades (as distinct from alleviating an individual prisoner's suffering from disease or reducing risk of infection), prison overcrowding has long been advanced as a justification for clemency (e.g., Judge, 1982; Kobil, 1991; Palenberg, 1983). Clemency has been used for this purpose in pre-pandemic Argentina, Thailand, St Kitts and Nevis, France, and the United States, among many other national jurisdictions in the twentieth and twenty-first centuries (Arias \& Kouroutakis, 2020; Pascoe, 2017; Nation News, 2 January 2017; Levy, 2007; Barkow, 2009; Love, 2010). It is through this existing framework that coronavirus clemency may be best understood. Moreover, as we have seen, coronavirus clemency ties to other existing retributive and redemptive justifications. While coronavirus clemency has not created an entirely new paradigm, what is different this time is the sheer scale of mass releases within particular jurisdictions, and the simultaneousness of clemency grants witnessed around the world, thereby providing national executives the chance to learn from and imitate each other's policies. ${ }^{9}$

Having considered global coronavirus clemency practice within the context of the prevailing academic literature, we also take five lessons for dealing with the Covid-19 pandemic and shaping criminal justice policy:

(a) Executives need not fear that pandemic-induced mass releases via clemency (as opposed to other procedural methods) might contravene the rule of law or the separation of powers, when there is already a long tradition of blanket pardons to alleviate prison overcrowding in democracies. Limiting the spread of infectious disease fits firmly within the long-established utilitarian, retributive and redemptive justificatory paradigms for clemency.

(b) Elected executives who remain reluctant to grant clemency in other contexts now have an opportunity to normalise some version of this practice in the eyes of the public. Executive clemency can become an uncontroversial legal and political tool to respond to individual mitigating circumstances, rehabilitation in prison, as well as utilitarian justifications such as prison overcrowding, assisting further investigations and healing civil conflict. In other words, Covid-19 has re-legiti-

\footnotetext{
${ }^{9}$ Comparative law provides some tools for analyzing how legal ideas diffuse across borders and how authorities 'share' and copy one another. Using executive clemency for prisoners at-risk of Covid-19 was an idea adopted rapidly across colonial divides and legal traditions. Despite its novelty for executive clemency, Covid-19 clemency became part of a broader public health strategy that was quickly implemented in many jurisdictions in their response to the virus. See, for instance, Watson's concept of 'legal borrowing' or Choudhry's concept of 'migration of constitutional ideas' (Choudhry, 2007; Watson, 1995).
} 
mised clemency as a policy tool, at least in some jurisdictions.

(c) The fairest way of releasing prisoners during a future epidemic or pandemic is generally to prioritise the physically vulnerable, and then those prisoners closest to completing their original sentences, with no blanket restrictions based upon offence category or prisoners' political orientation, even for prisoners originally convicted of serious international crimes. However, executives must also ensure that their actions, although well-intentioned, do not disincentivise vaccine adoption among prisoners. ${ }^{10}$

(d) Given the wide discretion that the clemency power affords executives, the advisory and documentary constraints on executive clemency generally serve important functions. Yet, in situations of emergency, it is possible to creatively fulfil or tweak these requirements to ensure that individual or mass pardon grants quickly achieve a policy objective. And finally,

(e) Even if executive clemency returns to fashion as a multifaceted policy tool in democracies, the mass releases witnessed during 2020 serve to sharpen the focus in individual jurisdictions on other reforms necessary to combat over-incarceration, such as progressive prosecution policies, sentencing reforms, liberalising parole eligibility, and compassionate release statutes. After all, executive clemency serves only as a very 'back-end' measure of discretion. Many other opportunities to reduce punitiveness exist at earlier phases of the criminal justice system (Barkow, 2015; Misner, 1996).

Globally, although at first glance the absolute numbers of released prisoners appear large, and mass clemency grants have already benefited a cross-section of vulnerable demographics, by the time of the most recent global count in June 2020, a mere six percent of prisoners around the world had been released through various procedural methods, including executive clemency (Harm Reduction International, 2020). This article has outlined the major clemency trends already witnessed over the ten months from March to December 2020, during the early phase of the Covid-19 pandemic. Although it is certain that prisoners will continue to be released across a range of jurisdictions, time will tell whether the trends identified in this article (particularly the withering of legal and bureaucratic barriers to clemency, exemptions for certain offenders and crimes, and the intermixing of executive clemency with other lenient

\footnotetext{
${ }^{10}$ For one example of ensuring mercy does not disincentivize vaccination, see Connecticut, where prisoners who are eligible for home release as a pandemic precaution become ineligible if they refuse a Covid-19 vaccine (Associated Press, 3 March 2021).
}

mechanisms) will persist until vaccines are more widely circulated. This article has demonstrated that the clemency power, much like the Covid-19 pandemic itself, retains nearuniversal relevance within the minds and decision-making of chief executives.

Funding The funded was provided by City University of Hong Kong, Grant No CityU 9048110.

\section{Declarations}

Conflict of interest On behalf of all authors, the corresponding author states that there is no conflict of interest.

\section{References}

ABC27 (2020). Board of Pardons schedule change due to coronavirus pandemic. Retrieved 19 August 2021, from https://www.abc27. com/news/local/harrisburg/board-of-pardons-schedule-changedue-to-coronavirus-pandemic

ABC News (2020). Myanmar releases more than 20,000 prisoners in mass pardon amid coronavirus outbreak. Retrieved 19 August 2021, from https://www.abc.net.au/news/2020-04-17/myanmarreleases-prisoners-amid-coronavirus-outbreak/12160388

Abrams, M. (2020). Covid 19 forces Pa. to move pardon, commutation proceedings online. KYW Newsradio. Retrieved 19 August 2021, from https://kywnewsradio.radio.com/articles/news/covid19-forces-pa-to-move-pardon-proceedings-online

Acker, J., et al. (2010). Merciful justice: Lessons from 50 years of New York death penalty commutations. Criminal Justice Review, 35(2), 183-199.

AdaDerana (2020). Sri Lanka aims to release at least 8,000 inmates from prisons. Retrieved 20 August 2021, from http://www.adade rana.1k/news/69762/sri-lanka-aims-to-release-at-least-8000inmates-from-prisons

Adebayo, A. (2020). 'COVID-19: Kwara constitutes prerogative of mercy advisory committee on release of prisoners. Daily Post. Retrieved 19 August 2021, from https://dailypost.ng/2020/04/ 15/covid-19-kwara-constitutes-prerogative-of-mercy-advisorycommittee-on-release-of-prisoners

Adepegba, A. (2020). COVID-19: NCoS releases 3,751 inmates. The Punch. Retrieved 20 August 2021, from https://punchng.com/ covid-19-ncos-releases-3751-inmates

AfricaNews (2020). Ex-Chadian dictator Hissene Habre returns to prison. Retrieved 20 August 2021, from https://www.africanews. com/2020/06/07/former-chadian-dictator-hissene-habre-retur ns-to-prison

AllAfrica (2020). Cameroon: President Biya's executive grant of clemency - over 180 inmates. freed in Bamenda. Retrieved 20 August 2021, from https://allafrica.com/stories/202004280607.html

Alshammari, Y.H. (2020). 'Behind Bahrain's royal pardon: Prisoners of conscience locked with Coronavirus. Inside Arabia. Retrieved 20 August 2021, from https://insidearabia.com/bahrain-royal-pardon-prisoners-of-conscience-locked-with-coronavirus

Anderson, A. F. (1989). AIDS and prisoners' rights law: Deciphering the administrative guideposts. The Prison Journal, 69(1), 14-26.

Andina (2020). Peru president: Criminals not to be released from jail due to COVID-19. Retrieved 20 August 2021, from https:// andina.pe/ingles/noticia-peru-president-criminals-not-to-be-relea sed-from-jail-due-to-covid19-795172.aspx

Arias, S., Kouroutakis, A. (2020). Separation of powers and executive clemency in the civil law world: A comparative study. In 
Executive clemency: Comparative and empirical perspectives (pp. 58-75). Routledge.

Asadu, C. (2020a). FG frees 2,600 prisoners over coronavirus. The Cable. Retrieved 20 August 2021, from https://www.thecable. ng/fg-frees-2600-prisoners-over-coronavirus

Asadu, C. (2020b). COVID-19: Buhari writes CJN, seeks release of more inmates. The Cable. Retrieved 19 August 2021, from https://www.thecable.ng/covid-19-buhari-writes-cjn-seeks-relea se-of-more-inmates

Associated Press. (2021). North Carolina prisons offer incentives for offenders to get COVID-19 vaccine. WYFF4. Retrieved 25 August 2021, from https://www.wyff4.com/article/north-carol ina-prisons-offer-incentives-for-offenders-to-get-covid-19-vacci ne/35372083

Associated Press. (2021). Inmates refuse inoculations in Connecticut federal prison. Boston Herald. Retrieved 25 August 2021, from https://www.bostonherald.com/2021/03/03/inmates-refuse-inocu lations-in-connecticut-federal-prison

Bangkok Post. (2020). Peru prison riot over coronavirus fears leaves nine dead. Retrieved 20 August 2021, from https://www. bangkokpost.com/world/1909768/peru-prison-riot-over-coron avirus-fears-leaves-nine-dead

Barkow, R. E. (2009). The politics of forgiveness: Reconceptualizing clemency. Federal Sentencing Reporter, 21(3), 153-159.

Barkow, R. E. (2015). Clemency and presidential administration of criminal law. New York University Law Review, 90(3), 802-869.

Barnett, J.D. (1926-1927). The grounds of pardon. American Institute of Criminal Law and Criminology, 17, 490-530.

Boston Globe (2020). Editorial: Baker's Parole Board stalls clemency process. Retrieved 19 August 2021, from https://www.bosto nglobe.com/2020/08/13/opinion/bakers-parole-board-stallsclemency-process

Briceño, F., Armario, C. (2020). Congress votes to oust Peru's president amid pandemic crisis. Associated Press News. Retrieved 20 August 2021, from https://apnews.com/article/virus-outbr eak-impeachments-peru-b7a731cbd7b1dc27a14f717e6f9ffc4a

Business World (2020). More than 58,000 prisoners released during pandemic. Retrieved 20 August 2021, from https://www.bworl donline.com/more-than-58000-prisoners-released-during-pande mic

CBS Boston. (2021). Massachusetts inmates will not get shorter prison sentences by getting COVID vaccine. Retrieved 25 August 2021, from https://boston.cbslocal.com/2021/02/03/massachusettsprison-inmates-coronavirus-vaccine-good-time-sentences

CBS San Francisco. (2021). Judge Rules CDCR Inflicted Cruel and Unusual Punishment on San Quentin Inmates During Massive COVID Outbreak. Retrieved 23 January 2022, from https://sanfr ancisco.cbslocal.com/2021/11/18/san-quentin-covid-outbreakcruel-unusual-punishment-cdcr-inmates/

Charles, J. (2020). Convicted rapists, killers among 415 prisoners granted presidential pardons in Haiti. Miami Herald. Retrieved 19 August 2021, from https://www.miamiherald.com/news/ nation-world/world/americas/haiti/article243926662.html

Choudhry, S. (2007). Migration as a new metaphor in comparative constitutional law. In S. Choudhry (Ed.), The migration of constitutional ideas (pp. 1-36). Cambridge.

Christin, A. (2018). Predictive algorithms and criminal sentencing. In D. Bessner \& N. Guilhot (Eds.), The decisionist imagination: Sovereignty, social Science and democracy in the 20th century (pp. 272-294). Berghahn Books.

Club of Mozambique News (2020). Mozambique: Assembly approves pardon and amnesty - AIM report. Retrieved 19 August 2021, from https://clubofmozambique.com/news/mozambique-assem bly-approves-pardon-and-amnesty-aim-report- 157167

Club of Mozambique News (2020). Nyusi announces pardon for prisoners. Retrieved 19 August 2021, from https://clubofmoza mbique.com/news/mozambique-nyusi-announces-pardon-forprisoners-180390

CNN Philippines (2020). DOJ streamlines process for parole, pardon to ease jail congestion. Retrieved 19 August 2021, from https:// cnnphilippines.com/news/2020/4/22/DOJ-streamline-parolepardon-jails.html

Cooper, S.L., Burrows, H. (2020). Remedying wrongful convictions: Comparisons between the royal prerogative of mercy in England and Wales and clemency in the USA. In Executive Clemency: Comparative and Empirical Perspectives (pp. 96-118). Routledge.

Cooper, S. L., \& Gough, D. (2014). The controversy of clemency and innocence in America. California Western Law Review, $51(1), 55-110$.

Cuiza, P. (2020). Dos condenados por narcotráfico, los primeros en beneficiarse con el indulto en Bolivia. La Razón. Retrieved 20 August 2021, from https://www.la-razon.com/nacional/2020/ 05/18/dos-condenados-por-narcotrafico-los-primeros-en-benef iciarse-con-el-indulto-en-bolivia

Daily Monitor (2020). Museveni pardons 833 prisoners countrywide. Retrieved 20 August 2021, from https://www.monitor.co.ug/ News/National/Museveni-pardons-833-prisoners-AttorneyGeneral-Cocid19/688334-5536982-ed9kg9/index.html

Diamoutene, S. (2020). COVID-19 : 1200 prisonniers en fin de peine graciés par le Président IBK. MaliWeb.net. Retrieved 20 August 2021, from https://www.maliweb.net/sante/covid19-1200-prisonniers-en-fin-de-peine-gracies-par-le-presidentibk-2866556.html

Dorne, C., \& Gewerthe, K. (1999). Mercy in a climate of retributive justice: Interpretations from a national survey of executive clemency procedures. New England Journal on Criminal and Civil Confinement, 25(2), 413-468.

Drinan, C. H. (2011). Clemency in a time of crisis. Georgia State University Law Review, 28(4), 1121-1157.

Dudgeon, J. A. (1980). Immunization in times ancient and modern. Journal of the Royal Society of Medicine, 73(8), 581-586.

Emirates News Agency (2020). President pardons 1,511 prisoners ahead of Ramadan. Retrieved 19 August 2021, from https:// wam.ae/en/details/1395302838156

Fox, R. G. (1999). When justice sheds a tear: The place of mercy in sentencing. Monash University Law Review, 25(1), 1-28.

Gernhart, G. (1999). A forgotten enemy: PHS's fight against the 1918 influenza pandemic. Public Health Reports, 114(6), 559-561.

GhanaWeb (2020). Akufo-Addo grants amnesty to 794 prisoners. Retrieved 19 August 2021, from https://www.ghanaweb.com/ GhanaHomePage/NewsArchive/Akufo-Addo-grants-amnestyto-794-prisoners-996865

Gobierno del Perú Press Release (2020). Más de 1500 personas salieron en libertad en el marco de las medidas adoptadas por el Ejecutivo para el deshacinamiento de los penales. Retrieved 20 August 2021, from https://www.gob.pe/institucion/minjus/ noticias/186712-mas-de-1-500-personas-salieron-en-libertaden-el-marco-de-las-medidas-adoptadas-por-el-ejecutivo-parael-deshacinamiento-de-los-penales

Godfrey, N. B., \& Rovner, L. L. (2020). COVID-19 in American prisons: Solitary confinement in not the solution. Arizona State University Law Journal Online, 2, 127-146.

Hafezi, P. (2020). Iran's supreme leader to pardon 10,000 prisoners, including political ones. Reuters. Retrieved 20 August 2021, from https://www.reuters.com/article/us-iran-prisoners-idUSK BN2153RN

Harm Reduction International (2020) COVID-19, prisons and drug policy. Retrieved 19 August 2021, from https://www.hri.global/ covid-19-prison-diversion-measures

Hashmi, F. (2020). Iranian authorities to continue decreasing prison population over COVID-19. UrduPoint. Retrieved 20 August 
2021, from https://www.urdupoint.com/en/world/iranian-autho rities-to-continue-decreasing-pr-974182.html

Hilton, T. (2020). UAE President orders release of 1,511 prisoners. Saudi Gazette. Retrieved 19 August 2021, from https://www. saudigazette.com.sa/article/592171

Hodgin, M.S. (2020). Parole hearings will resume with 'reduced person to person interaction. Retrieved 19 August 2021, from https:// wbhm.org/feature/2020/parole-hearings-will-resume-reducedperson-person-interaction

Høiby, N. (2020). Pandemics: Past, present, future. Journal of Pathology, Microbiology and Immunology, 129(7), 352-371. https:// doi.org/10.1111/apm.13098

Human Rights Watch (2020). Covid-19 Prisoner Releases Too Few, Too Slow. Internet Archive. Retrieved 19 August 2021, from https:// web.archive.org/web/20200627011143/https://www.hrw.org/ news/2020/05/27/covid-19-prisoner-releases-too-few-too-slow

ICF UAE News (2020). 515 UAE prisoners pardoned ahead of Eid Al Adha, no political prisoners included. Retrieved 19 August 2021, from http://www.icfuae.org.uk/news/515-uae-prisoners-pardo ned-ahead-eid-al-adha-no-political-prisoners-included

Inusah, R. (2018). President Akufo-Addo urged to grant amnesty to prisoners. GBC Ghana. Retrieved 19 August 2021, from https:// www.gbcghanaonline.com/news/politics/president-akufo-addourged-to-grant-amnesty-to-prisoners/2018

Jibril, H. (2020). Algerian president pardons over 5,000 prisoners. Anadolou Agency. Retrieved 20 August 2021, from https://www. aa.com.tr/en/africa/algerian-president-pardons-over-5-000-priso ners $/ 1788147$

Joy Online (2020). Akufo-Addo pardons over 800 prisoners. Retrieved 19 August 2020, from https://www.myjoyonline.com/presidentnana-akufo-addo-has-freed-808-prisoners-on-the-recommenda tion-of-the-prisons-service-council

Judge, F. T. (1982). Relief for prison overcrowding: Evaluating Michigan's accelerated parole statute. University of Michigan Journal of Law Reform, 15, 547-576.

Khan, S. (2020). COVID-19: Afghanistan pardons over 12,000 prisoners. AA. Retrieved on 19 August 2021, from https://www.aa. com.tr/en/asia-pacific/covid-19-afghanistan-pardons-over-12000 -prisoners $/ 1820251$

Kindzeka, M.E. (2020). 'Cameroonian president orders de-crowding of prisons to combat COVID-19. Voice of America News. Retrieved 19 August 2021, from https://www.voanews.com/africa/camer oonian-president-orders-de-crowding-prisons-combat-covid-19

Kinner, S. A., Young, J. T., Snow, K., Southalan, L., Lopez-Acuña, D., Ferreira-Borges, C., \& O'Moore, E. (2020). Prisons and custodial settings are part of a comprehensive response to COVID-19. Lancet, 5(4), E188-E189.

Kobil, D. T. (2003). How to grant clemency in unforgiving times. Capital University Law Review, 31(2), 219-242.

Kobil, D. T. (1991). Quality of mercy strained: Wresting the pardoning power from the King. Texas Law Review, 69(3), 569-642.

Kovarsky, L. (2020). Pandemics, risks, and remedies. Virginia Law Review Online, 106, 71-98.

Laird, L. (2017). Clemency calling. ABA Journal, 103, 18-19.

Lachsz, A., \& Hurley, M. (2021). Why practices that could be torture or cruel, inhuman and degrading treatment should never have formed part of the public health response to the COVID-19 pandemic in prisons. Current Issues in Criminal Justice, 33(1), 54-68. https://doi.org/10.1080/10345329.2020.1863310

Levy, R. (2007). Pardons and amnesties as policy instruments in contemporary France. Crime and Justice, 36, 551-590.

Love, M. C. (2001). Fear of forgiving: Rule and discretion in the theory and practice of pardoning. Federal Sentencing Reporter, 13(3-4), $125-133$.

Love, M. C. (2010). The twilight of the pardon power. Journal of Criminal Law and Criminology, 100(3), 1169-1212.
Maphosa, V. (2020a). 1680 Prisoners Set Free. All Africa. Retrieved 20 August 2021, from https://allafrica.com/stories/2020a04020 252.html

Maphosa, V. (2020b). 2,528 More Prisoners Released. All Africa. Retrieved 19 August 2021, from https://allafrica.com/stories/ 2020b05060796.html

Masina, L. (2020). Malawi president pardons prisoners to reduce COVID-19 spread. Voice of America News. Retrieved 19 August 2021, from https://www.voanews. com/covid-19-pandemic/malawi-president-pardons-priso ners-reduce-covid-19-spread

McCoy, T. (2009). Legal ideology in the aftermath of rebellion: The convicted First Nations participants, 1885. Histoire Sociale/ social History, 42(83), 175-201.

Michael, I. (2020) Covid-19: Gombe govt pardons 28 inmates to fight spread. Nigerian Tribune. Retrieved 20 August 2021, from https://tribuneonlineng.com/covid-19-gombe-govt-pardons-28inmates-to-fight-spread

Middle East Eye (2020). Coronavirus: Morocco's king pardons 5,654 prisoners to avoid contagion. Retrieved 19 August 2021, from https://www.middleeasteye.net/news/coronavirus-moroccosking-mohammed-vi-pardons-5654-prisoners-avoid-contagion

Miller, V.M.L. (1998). Violent crime, sexual deviancy and executive clemency in Florida, 1889-1918. PhD thesis, Open University.

Minow, M. (2019). When should law forgive? WW Norton.

Misner, R. L. (1996). Recasting prosecutorial discretion. The Journal of Criminal Law and Criminology, 86(3), 717-777.

Moore, K. D. (1989). Pardons: Justice, Mercy, and the Public Interest.

Nasrallah, T. (2020). UAE announces 490 new coronavirus cases, three deaths. Retrieved 19 August 2021, from https://gulfnews.com/ uae/uae-announces-490-new-coronavirus-cases-three-deaths-1. 1587467539359

Nation News (2017). St Kitts and Nevis to address overcrowding at prison. Retrieved 20 August 2021, from https://www.natio nnews.com/2017/01/02/st-kitts-and-nevis-to-address-overcrowdi ng-at-prison

New York State Governor's Office (2020). Governor Cuomo grants clemency to three individuals. Retrieved 20 August 2021, from https://www.governor.ny.gov/news/governor-cuomo-grantsclemency-three-individuals

Ngatane, N. (2020). COVID-19: Botswana Pardons and Releases 149 Prisoners. Eyewitness News. Retrieved 19 August 2021, from https://ewn.co.za/2020/04/17/covid-19-botswana-to-pardonedand-release-149-prisoners

Novak, A. (2016a) Pardon power. Max Planck Encyclopedia of Comparative Constitutional Law. Retrieved 19 August 2021, from https://oxcon.ouplaw.com/view/10.1093/law:mpeccol/law-mpecc ol-e405

Novak, A. (2016b) Comparative executive clemency: The constitutional pardon power and the prerogative of mercy in global perspective. Routledge.

Novak, A. (2016c). Transparency and comparative executive clemency: Global lessons for pardon reform in the United States. University of Michigan Journal of Law Reform, 49(4), 817-851.

Novak, A., Pascoe, D. (2020). Emerging trends and best practices in comparative clemency. In D. Pascoe \& A. Novak (Eds.) Executive clemency: Comparative and empirical perspectives (pp. 187-212). Routledge.

Nowotny, K. M., Seide, K., \& Brinkley-Rubenstein, L. (2021). Risk of COVID-19 infection among prison staff in the United States. BMC Public Health, 21, 1036. https://doi.org/10.1186/ s12889-021-11077-0

Nwankwo, S. (2020). Abia Gov pardons 32 inmates. The Nation (Nigeria). Retrieved 19 August 2021, from https://thenationonlineng. net/abia-gov-pardons-32-inmates 
Osuyi, P. (2020). Covid-19: Delta governor pardons 150 inmates. The Sun. Retrieved 20 August 2021, from https://www.sunnewsonl ine.com/covid-19-delta-government-pardons-150-inmates

Palenberg, J. C. (1983). Mass amnesty: The East German answer to prison overcrowding. American Journal of Criminal Law, 11, 369-385.

Pascoe, D. (2017). Singapore and Thailand: Explaining differences in death penalty clemency. In J. Liu, M. Travers \& L.Y.C. Chang (Eds.) Comparative criminology in Asia (pp. 165-184). Springer.

Pascoe, D. (2019a) Towards a global theory of capital clemency incidence. In C.S. Steiker \& J.M. Steiker (Eds.) Comparative Capital Punishment (pp. 116-136). Edward Elgar.

Pascoe, D. (2019b) Last chance for life: Clemency in Southeast Asian death penalty cases. Oxford.

Pascoe, D., Novak, A. (2020a) Executive clemency: A ubiquitous part of the constitutional scheme. In D. Pascoe \& A. Novak (Eds.) Executive clemency: Comparative and empirical perspectives (pp. 1-35). Routledge.

Pascoe, D., Novak, A. (2020b) Appendix. In D. Pascoe \& A. Novak (Eds.) Executive clemency: Comparative and empirical perspectives (no pagination). Routledge.

Pazzibugan, D.Z. (2020). DOJ: New rules on pardon, parole to wait 15 days more. Philippine Daily Inquirer. Retrieved 19 August 2021, from https://newsinfo.inquirer.net/1267718/ doj-new-rules-on-pardon-parole-to-wait-15-days-more

Petesch, C. (2020). Chad's ex-dictator granted home arrest amid virus threat. ABC News. Retrieved 20 August 2021, from https:// abcnews.go.com/International/wireStory/chads-dictator-grant ed-home-arrest-amid-virus-threat-70016047

Philippine Daily Inquirer. (2021) 2500 convicts released from various prisons. Retrieved 20 August 2021, from https://newsinfo.inqui rer.net/1378484/2500-convicts-released-from-various-prisons

Raache, H. (2020). Gov. Stitt approves hundreds of prison commutations to mitigate coronavirus spread. KFOR-TV. Retrieved 19 August 2021, from https://kfor.com/health/coronavirus/gov-stittapproves-hundreds-of-prison-commutations-to-mitigate-coron avirus-spread

Reuters. (2020). Death toll in Peru prison riot over coronavirus demand rises to nine. Retrieved 20 August 2021, from https://www. usnews.com/news/world/articles/2020-04-28/at-least-three-inmat es-dead-after-peruvian-prison-riot-over-coronavirus

Seal, L. (2014). Capital punishment in twentieth-century Britain: Audience, justice, memory. Routledge.

Sediqi, A.Q., Shalizi, H. (2020) Afghanistan to release 10,000 prisoners to slow spread of coronavirus. Reuters. Retrieved 19 August 2021, from https://www.reuters.com/article/us-health-coronavirus-afghanistan-prison/afghanistan-to-release-10000-prisonersto-slow-spread-of-coronavirus-idUSKBN21D334

Sharma, D., Li, W., Lavoie, D., Lauer, C. (2020). U.S. prison population down $8 \%$ amid coronavirus outbreak. Daily Herald. Retrieved 19 August 2021, from https://www.dailyherald.com/ news/20200716/us-prison-populations-down-8-amid-coronavirus-outbreak

Shelton, T. (2020). Iran releases 85,000 prisoners to curb coronavirus spread, but Australian academic remains behind bars. ABC News. Retrieved 19 August 2021, from https://www.abc.net.au/news/ 2020-03-20/coronavirus-covid-19-iran-releases-85,000-priso ners/12073630

Sikkink, K. (2011). The justice cascade: How human rights prosecutions are changing world politics. WW Norton.

Skene, L. (2020). Louisiana's longest serving female inmate hospitalized with coronavirus while clemency request stalls. The Advocate. Retrieved 19 August 2021, from https://www.theadvocate. com/baton_rouge/news/coronavirus/article_d60d1896-84de11ea-a373-a734e11b21f8.html

Slattery, D. (2020). NY prison officials defend coronavirus response despite 5\% infection rate. New York Daily News. Retrieved 20 August 2021, from https://www.nydailynews.com/news/politics/ ny-new-york-state-prisons-defend-coronavirus-response-20200 922-brbddhoeh5eklmlcogivdcamje-story.html

SNS Web (2020). Afghanistan govt to release prisoners amid Coronavirus pandemic. Retrieved 19 August 2021, from https://www. thestatesman.com/world/afghanistan-govt-release-prisonersamid-coronavirus-pandemic-1502870404.html

Speri, A. (2020). As Coronavirus spreads behind bars, prisons release very few people. The Intercept. Retrieved 19 August 2021, from https://theintercept.com/2020/05/14/prison-release-coronavirus

Straits Times (2020). Chile to pardon 1,300 prisoners to halt coronavirus spread. Retrieved 20 August 2021, from https://www.strai tstimes.com/world/americas/chile-to-pardon-1300-prisoners-tohalt-coronavirus-spread

Strange, C. (1996). Introduction. In C. Strange (Ed.) Qualities of mercy: Justice, punishment, and discretion. UBC Press.

Sudhi, K.S. (2020). 'Amnesty scheme for aged prisoners sought. The Hindu. Retrieved 20 August 2021, from https://www.thehindu. $\mathrm{com} /$ news/national/kerala/amnesty-scheme-for-aged-prisonerssought/article31281542.ece

Taxman, F. (Ed.) (2017). Handbook on Risk and Need Assessment: Theory and Practice. Routledge.

Thomas, D. (2012). Judicial discretion in sentencing. In L. Gelsthorpe \& N. Padfield (Eds.), Exercising discretion: Decision-making in the criminal justice system and beyond (pp. 50-73). Routledge.

Trotter, M. (2020). As COVID-19 risk Grows in prisons, Oklahoma Pardon and Parole Board may streamline commutations. Public Radio Tulsa. Retrieved 19 August 2021, from https://www.publi cradiotulsa.org/post/covid-19-risk-grows-prisons-oklahoma-pardon-and-parole-board-may-streamline-commutations

Uganda Radio Network (2020). COVID-19: Museveni pardons 833 prisoners. The Observer. Retrieved 19 August 2021, from https:// observer.ug/news/headlines/64506-covid-19-museveni-pardons833-prisoners

van Wagtendonk, A. (2020). Muskegon inmate with coronavirus receives meeting with parole board after AG support. MLive. Retrieved 19 August 2021, from https://www.mlive.com/news/ muskegon/2020/08/muskegon-inmate-with-coronavirus-recei ves-meeting-with-parole-board-after-ag-support.html

Vanguard (2020). 'Gov Fayemi plans to decongest correctional centre to curb COVID-19 spread. Retrieved 19 August 2021, from https://www.vanguardngr.com/2020/04/gov-fayemi-plans-todecongest-correctional-centre-to-curb-covid-19-spread

Watson, A. (1995). From legal transplants to legal formants. American Journal of Comparative Law, 43(3), 469-476.

Wessely, S. (2006). The life and death of Private Henry Farr. Journal of the Royal Society of Medicine, 99(9), 440-443.

Widra, E., Hayre, D. (2020). Failing grades: States' responses to COVID-19 in jails and prisons. Prison Policy Initiative. Retrieved 19 August 2021, from https://www.prisonpolicy.org/ reports/failing_grades.html

Wiley, H. (2020). Gavin Newsom commutes prison sentence for 21 California inmates, pardons 5 more. Sacramento Bee. Retrieved 19 August 2021, from https://www.sacbee.com/news/politicsgovernment/capitol-alert/article241573671.html

Wolfe, G. B. (2007). I beg your pardon: A call for renewal of executive clemency and accountability in Massachusetts. Boston College Third World Law Journal, 27, 417-454. 
World Health Organization. (2020). UNODC, WHO, UNAIDS and OHCHR joint statement on COVID-19 in prisons and other closed settings. Retrieved 23 January 2022, from https://www. who.int/news/item/13-05-2020-unodc-who-unaids-and-ohchrjoint-statement-on-covid-19-in-prisons-and-other-closed-settings

Xinhua (2020). Somali president pardons 148 prisoners to contain spread of COVID-19. Retrieved 19 August 2021, from http:// www.xinhuanet.com/english/2020-04/02/c_138941447.htm
ZimEye (2020). Clemency order extended to clear prisons of all bedridden prisoners. Retrieved 20 August 2021, from https://www. zimeye.net/2020/05/01/clemency-order-extended-to-clear-priso ns-of-all-bedridden-prisoners 